\title{
Alternative Strategies of Credit Risk Management: A Successful Case Study of the Guangdong Nanyue Bank in China From 2011 to 2016
}

\author{
Bhabani Shankar Nayak ${ }^{1} \&$ Jia $\mathrm{Xu}^{2}$ \\ ${ }^{1}$ Coventry Business School, Coventry University, Coventry, UK \\ ${ }^{2}$ Anhui Rende Chuanghe Investment Management Co. Ltd., Anhui, China \\ Correspondence: Dr Bhabani Shankar Nayak, Senior Lecturer in Business Strategy, Coventry Business School, \\ Coventry University, Coventry, UK.
}

Received: August 22, 2018

Accepted: September 4, 2018

Online Published: September 11, 2018

doi:10.5430/jms.v9n4p1

URL: https://doi.org/10.5430/jms.v9n4p1

\begin{abstract}
Guangdong Nanyue Bank (GNB) shows the alternative strategies of credit risk management which led to its growth. It was formed out of local government finances and enterprise shares but spread its base to six cities and ranked as one of the top ten banks in the country. Since its establishment, the bank has been adhering to its market positioning: serving small and medium-sized enterprises, serving local citizens and serving trade financing. In order to better regulate the credit approval procedures and improve the credit level of decision-making, GNB has developed a set of applicable measures for the management of credit risk, set up corresponding departments and allocated professional staff for credit risk control before approval of loan, during the loan, and after the loan. The paper looks at the alternative strategies followed by GNB to manage credit risk and grow successfully within the banking industries in China.
\end{abstract}

Keywords: alternative strategies, credit, risk, management, China

\section{Introduction}

Guangdong Nanyue Bank (GNB) was founded in January 1998 and registered in Zhanjiang city in Guangdong province which is the southernmost coastal city of China. As a local commercial bank, it was formed out of local government finances and enterprise shares. It has a registered capital of 4 billion 620 million yuan and employs 2,000 people. Its main branches are located in the six cities: Guangzhou, Shenzhen, Chongqing, Changsha, Foshan and Dongguan. It has a subsidiary called Zhongshan Ancient Town Nanyue Village Bank. Among 130 city commercial banks in China, the current asset size of GNB is ranked within the top ten banks (GNB, 2017).

Since its establishment, the bank has been adhering to its market positioning: serving small and medium-sized enterprises, serving local citizens and serving trade financing. After nineteen years of development, GNB has achieved a leap from being a local commercial bank to a regional joint-stock commercial bank. With continuous improvement in its operation and management level, it achieved good ratings from the China Banking Regulatory Commission (CBRC). It has been rated second in the past four years. In 2011, it was rated '2B' which is the highest rating of Chinese city commercial banks (GNB, 2017).

In order to better regulate the credit approval procedures and improve the credit level of decision-making, GNB has developed a set of applicable measures for the management of credit risk, set up corresponding departments and allocated professional staff for credit risk control before approval of loan, during the loan, and after the loan (Ye, 2017).

\section{Systemic Credit Risk Management in the GNB}

According to the expected loss of credit assets, the China Banking Regulatory Commission (CBRC) usually divides loans into five categories: Normal, Special mention, Sub-standard, Doubt and Loss. In order to measure credit risk more accurately, GNB divides the credit assets into ten categories based on the five categories. In Table 1, the smaller the number, the higher the security of credit assets. The risk level of credit assets is determined by the level of credit risk of the borrower and the guarantor (Cai, 2015). The GNB has classified different levels of loan in following terms which guides its operations of credit risk management. 
Table 1. From five to ten different levels of classification of loans

\begin{tabular}{|c|c|c|c|}
\hline $\begin{array}{l}\text { Five level } \\
\text { classification }\end{array}$ & Definition & $\begin{array}{l}\text { Ten level } \\
\text { classification }\end{array}$ & Definition \\
\hline \multirow[t]{5}{*}{ Normal } & \multirow{5}{*}{$\begin{array}{l}\text { The borrower is able to } \\
\text { execute the contract, there is } \\
\text { no reason to doubt that the } \\
\text { principal and interest of the } \\
\text { credit assets cannot be repaid } \\
\text { in full and on time. }\end{array}$} & Normal 1 & $\begin{array}{l}\text { The borrower's ability to repay and the } \\
\text { willingness to repay is very strong, and } \\
\text { there is very ample evidence that credit } \\
\text { assets can be repaid on time. }\end{array}$ \\
\hline & & Normal 2 & $\begin{array}{l}\text { Borrowers have a very strong repayment } \\
\text { ability and willingness to repay, and } \\
\text { there is sufficient evidence that credit } \\
\text { assets can be repaid on time. }\end{array}$ \\
\hline & & Normal 3 & $\begin{array}{l}\text { Borrowers have a strong willingness to } \\
\text { repay and repayment ability, there is no } \\
\text { reason to doubt that credit assets cannot } \\
\text { be repaid on time. }\end{array}$ \\
\hline & & Normal 4 & $\begin{array}{l}\text { Borrowers have a strong willingness to } \\
\text { repay and repayment ability, there is no } \\
\text { sufficient reason to doubt that credit } \\
\text { assets cannot be repaid on time. }\end{array}$ \\
\hline & & Normal 5 & $\begin{array}{l}\text { Borrowers have a willingness to repay } \\
\text { and repayment ability, there is no } \\
\text { sufficient reason to doubt that credit } \\
\text { assets cannot be repaid on time. }\end{array}$ \\
\hline \multirow[t]{2}{*}{$\begin{array}{l}\text { Special } \\
\text { mention }\end{array}$} & \multirow[t]{2}{*}{$\begin{array}{l}\text { Although borrowers } \\
\text { currently have the ability to } \\
\text { repay principal and interest } \\
\text { and other obligations, they } \\
\text { will still have default risk. }\end{array}$} & $\begin{array}{l}\text { Special } \\
\text { mention } 1\end{array}$ & $\begin{array}{l}\text { Although there are factors that adversely } \\
\text { affect the repayment, the risk mitigation } \\
\text { effect is good and the expected credit } \\
\text { assets can be recovered for a period of } \\
\text { time after maturity. }\end{array}$ \\
\hline & & $\begin{array}{l}\text { Special } \\
\text { mention } 2\end{array}$ & $\begin{array}{l}\text { Although there are factors that have a } \\
\text { major adverse impact on repayment, } \\
\text { there is still evidence that appropriate } \\
\text { measures can be taken to recover credit } \\
\text { assets within a short period of time after } \\
\text { maturity. }\end{array}$ \\
\hline
\end{tabular}

\begin{tabular}{|c|c|c|}
\hline Substandard & $\begin{array}{l}\text { The debtor's solvency is } \\
\text { clearly a problem. They are } \\
\text { unable to repay the loan } \\
\text { principal and interest in full. }\end{array}$ & Subst \\
\hline Doubt & $\begin{array}{l}\text { If the debtor fails to repay } \\
\text { the principal and interest of } \\
\text { the loan in full, he will suffer } \\
\text { greater losses even if he has } \\
\text { executed the guarantee. }\end{array}$ & Doub \\
\hline Loss & $\begin{array}{l}\text { After all measures are taken, } \\
\text { principal and interest cannot } \\
\text { be recovered or only a small } \\
\text { part can be recovered. }\end{array}$ & Loss \\
\hline
\end{tabular}

Source: $\quad$ GNB $\quad$ Annual $\quad$ Report $2011-2016, \quad$ Retrieved $\quad$ June $\quad 18, \quad 2018$ from
http://www.gdnybank.com/tzzgx/index.html\#mao_c 
In the framework of credit risk management, GNB studied the experience of the Western commercial banks. The loan business is divided into three lines - marketing line, risk line and operations line. The marketing line includes corporate finance, personal finance, financial markets, investment banking, small and micro- businesses and branches at all levels. The operations line includes the operation management department, science and technology department, network bank, audit department, manpower department, comprehensive department and the finance department. The risk line includes the Head Office risk management department and branch risk management departments. The Head Office risk management department is responsible for the credit risk management of the whole bank. The head office risk management department evaluates the performance of leaders in all branch risk management departments without any influence of the marketing line and operations line (Yang, 2015).

The credit risk management process in GNB is divided into three parts: before a loan, during the loan, and after the loan. Before a loan, the management of credit risk usually includes three aspects: the examination of credit application materials before credit is approved and the evaluation of customer credit rating. During the loan, the principle of separating the loan business department from the loan approval department must be strictly adhered to in order to avoid the situation that blindly pursuing the profits and ignoring the huge defaults (Kong, 2014). After the loan, the local branches need to inspect the use of loans, revisit customers monthly and classify credit assets regularly. When a risk associated with credit assets arises, the local branches need to take measures for disposing of non-performing loans and report the real condition to the Head Office (Liu, 2014).

\section{Operation and Quality of Credit Assets}

In 2016, Chinese regulators required banks to continue to strengthen their internal control and risk management in terms of their loans to local governments, companies, real estate industry and off-balance sheet business. Under this regulatory background, GNB realized that the transition from passive to active risk control and made the main risk indicators meet regulatory requirements (Wang, 2013).

Table 2. The core indicators of credit risk supervision of the GNB from 2011 to 2016

\begin{tabular}{|c|c|c|c|c|c|c|c|}
\hline Risk index & $\begin{array}{l}\text { Standard } \\
\text { value }\end{array}$ & Dec 2011 & Dec 2012 & Dec 2013 & Dec 2014 & Dec 2015 & Dec 2016 \\
\hline $\begin{array}{l}\text { Non-Performing } \\
\text { Loan(NPL) ratio }(\%)\end{array}$ & $\leq 5$ & 1.08 & 1.48 & 1.43 & 1.26 & 1.76 & 1.87 \\
\hline $\begin{array}{l}\text { Credit concentration } \\
\text { degree of a single } \\
\text { customer }(\%)\end{array}$ & $\leq 15$ & 13.21 & 10.24 & 7.15 & 6.22 & 6.52 & 5.35 \\
\hline $\begin{array}{l}\text { Loan } \begin{array}{l}\text { concentration of } \\
\text { a } \\
\text { customer }(\%)\end{array} \\
\text { group }\end{array}$ & $\leq 10$ & 10.10 & 6.51 & 4.51 & 6.22 & 9.41 & 10.30 \\
\hline $\begin{array}{l}\text { Credit concentration of } \\
\text { the largest ten group } \\
\text { customers }(\%)\end{array}$ & $\leq 100$ & 60.20 & 56.67 & 57.77 & - & - & - \\
\hline Total correlation $(\%)$ & $\leq 50$ & - & 19.52 & 12.99 & 3.94 & 14.67 & 15.23 \\
\hline rce: $\quad$ GNB $\quad$ Ann & al $\quad \mathrm{R}$ & ort 20 & -2016 & Retrieved & June & 18 & 018 \\
\hline
\end{tabular}

By following empirical evidences from the above indicators in the Table-2, Yang (2016) argued that the credit operation of GNB was in good condition with no major risk vulnerabilities between 2011 and 2016. This is because the rate of non-performing loans was effectively controlled. Despite the rate of non-performing loan was only $1.08 \%$ in 2011, the non-performing loan ratios for the rest of the years were relatively stable at around $1.56 \%$. In 2016, there was a slight increase in the non-performing loan ratio relative to that in 2015. Meanwhile, the credit concentration degree decreased significantly. The credit concentration of a single group customer and the maximum single group customer loan concentration are all important indicators of credit risk supervision. Since 2011, GNB has taken effective measures and customer concentration and loan concentration have decreased significantly. The entire correlation degree has also obviously reduced. The whole correlation degree is the ratio of the total amount of credit 
of all related parties to net capital. The bigger the indicator, the greater the credit risk faced by the banks. In 2013, GNB shifted from risk control to active risk management and after that the whole correlation degree went into sharp decline, down by $6.51 \%$. However, the fluctuations of the whole correlation degree were large, reaching its lowest level in 2014 by $3.94 \%$, and rising to $15.23 \%$ again by 2016 . Overall, this indicator meets the regulatory requirement (GNB, 2016).

Tables 3 and 4 show that the GNB is expanding. The entire loan and deposit business developed strongly from 2015 to 2016. The total amount of loans was 81,182 million yuan by the end of 2016 while the non-performing loans' total was 1,518 million yuan, which was an increase of 277 million yuan comparing to the non-performing loans at the end of 2015 (GNB, 2016).

Table 3. The main business of the GNB in 2015 and 2016

\begin{tabular}{|llll|}
\hline Item & December 2016 & December 2015 & Year-on-year change(\%) \\
& $81,181,983$ & $70,514,411$ & 15.13 \\
\multicolumn{1}{c}{ Corporate loans } & $62,740,090$ & & \\
$\quad$ Individual loans & $12,549,365$ & $56,468,456$ & 11.11 \\
\multicolumn{1}{c}{ Discount } & $5,892,528$ & $9,701,882$ & 29.35 \\
\hline Deposits & $127,316,189$ & $4,344,073$ & 35.65 \\
\hline & & $110,813,115$ & 14.89 \\
Corporate deposits & $83,316,291$ & & 3.35 \\
Individual deposits & $14,426,516$ & $80,617,379$ & 11.08 \\
Others & $29,573,382$ & $12,987,872$ & 71.86 \\
\hline
\end{tabular}

Unit: Thousand yuan

Source: GNB annual report 2016, (Zhanjiang: Guangdong Nanyue Bank Press, 2016), p. 15

Table 4. The capital adequacy ratios of the GNB in 2015 and 2016

\begin{tabular}{|llll|}
\hline Item & $\begin{array}{l}\text { December } \\
\mathbf{2 0 1 6}\end{array}$ & $\begin{array}{l}\text { December } \\
\mathbf{2 0 1 5}\end{array}$ & $\begin{array}{l}\text { Year-on-year } \\
\text { change(\%) }\end{array}$ \\
\hline Capital adequacy ratio & $11.82 \%$ & $10.95 \%$ & $\uparrow$ \\
\hline Tier one capital adequacy ratio & $9.63 \%$ & $8.83 \%$ & $\uparrow$ \\
\hline Core tier one capital adequacy ratio & $9.63 \%$ & $8.82 \%$ & $\uparrow$ \\
\hline leverage ratio & $5.62 \%$ & $5.13 \%$ & $\uparrow$ \\
\hline
\end{tabular}

Source: GNB Annual Report 2016, (Zhanjiang: Guangdong Nanyue Bank Press, 2016), p. 15

Meanwhile, the China Banking Regulatory Commission required the bank's capital adequacy ratio and core capital adequacy ratio to be $10.5 \%$ and $8.5 \%$ respectively. GNB achieved $11.82 \%$ and $9.63 \%$, which just met the regulatory targets (Liu, 2014). It is encouraging that the GNB coordinated the relationship between explosive operations and potential liquidity crises as seen in Table 5. Its qualified high-quality liquid assets can cover the net cash outflows over the next thirty days in 2016 if needed (GNB, 2016). 
Table 5. The liquidity coverage of the GNB in 2016

\begin{tabular}{|l|l|}
\hline Item & December $\mathbf{2 0 1 6}$ \\
\hline Liquidity coverage & $118.37 \%$ \\
\hline Qualified high-quality liquid assets(10000 yuan ) & $2,073,985$ \\
\hline Net cash outflows over the next $\mathbf{3 0}$ days (10000 yuan) & $1,752,095$ \\
\hline
\end{tabular}

Source: GNB Annual Report 2016, (Zhanjiang: Guangdong Nanyue Bank Press, 2016), p. 15

\section{Latest Credit Operations and Forecasts}

2016 was the first year of China's implementation of the thirteenth five-year plan, which was a crucial period for the upgrading of industrial structure and financial reform. At the same time, this year was also GNB's key period to perform credit system reform during which the credit risk presented new features.

As Figure 1 shows, as of April 2017, the non-performing loan ratio of GNB was 1.36\%, which exceeded the budget by $0.02 \%$. There were two reasons for this: first, the decline in the scale of loans was the main reason for the non-performing loan rate over budget. The planned size of the whole loan amount was 47 billion 600 million yuan but the actual amount was 44 billion 900 million yuan, and then the loan scale budget gap was 2 billion 700 million yuan. This led to a $0.07 \%$ rise in non-performing loan ratio. Secondly, the total amount of non-performing loans (612 million yuan) is 24 million yuan lower than the budget, which led to a $0.05 \%$ reduction in the non-performing loan ratio. In summary, the non-performing loan ratio exceeded the budget by $0.02 \%$. Although the total amount of non-performing loans was controlled within the scope of the budget, the loan scale did not complete the budget and the gap reached 2 billion 700 million yuan by April 2017, resulting in bad loan rates over budget indicators. Therefore, in controlling the bad loan balance, the bank will strive for a greater balance of loans (GNB, 2016).

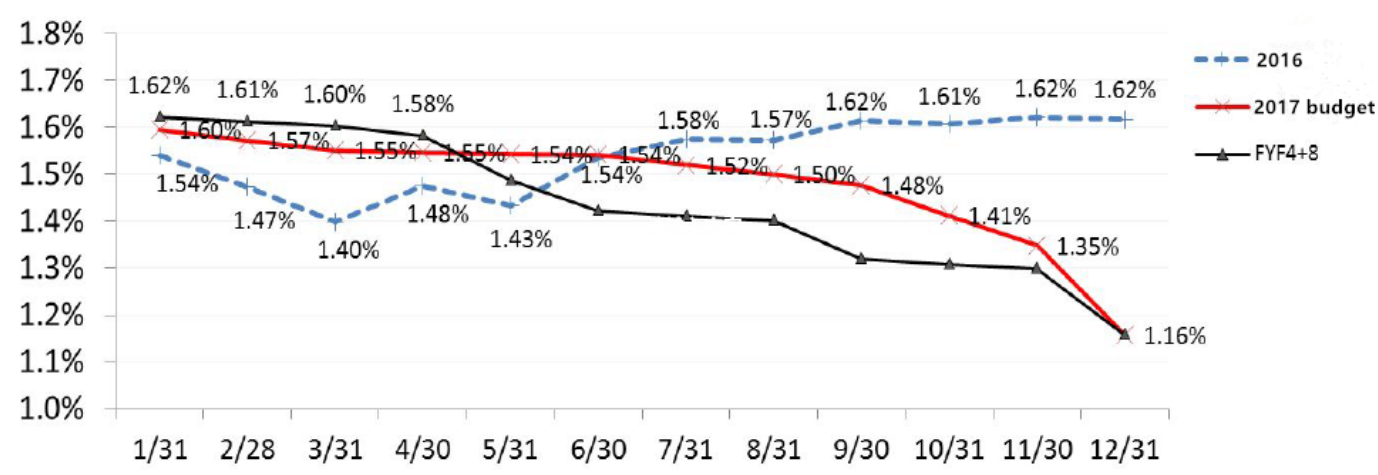

Figure 1. GNB's non-performing loan ratios in 2017 budget

Source: GNB, Retrieved June 18, 2018 from http://www.gdnybank.com/index.html

In Figure 2, the non-performing loan rate of mortgage business has always been higher than the budget by 0.2-0.5 percentage points since 2017. The main reason is that the loan balance is 37 billion 700 million yuan, which is less than the budget amount of 1 billion 800 million. The deeper reason is that the real estate industry has not yet warmed up as the government has yet to relax the regulation of the real estate industry while the demand side is in a wait-and-see state. A number of data show that the volume of commercial housing transactions declined significantly. On one hand, this has resulted in fewer loans for individuals and a decline in the amount of bank loans. On the other hand, the real estate business cannot sell houses and cannot gain profits. Therefore, they cannot repay loans resulting in increased non-performing loans for the bank (Ye, 2017). 


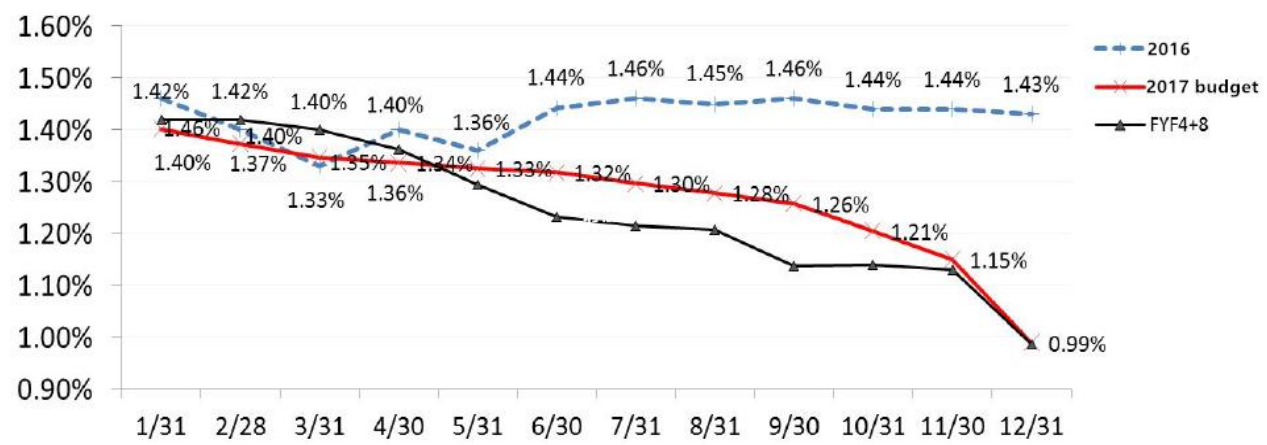

Figure 2. The non-performing loan ratios of the mortgage in the GNB in 2017 budget

Source: GNB, Retrieved June 18, 2018 http://www.gdnybank.com/index.html

As shown in Figure 3, the small and medium-sized enterprise loan business of GNB amounted to 3 billion 869 million yuan by the end of April 2016, which showed a year-on-year growth of 2 billion 93 million yuan (an increase of $117.85 \%$ ). The rate of non-performing loans for small and medium enterprises continued to decline and the below budget scale became larger. By the end of April 2017, the non-performing loan ratio of small and medium enterprises had achieved a good result of being below the budget by $0.09 \%$ (GNB, 2016). It can be seen that the GNB deserves recognition in the efforts of small and medium firm loan business.

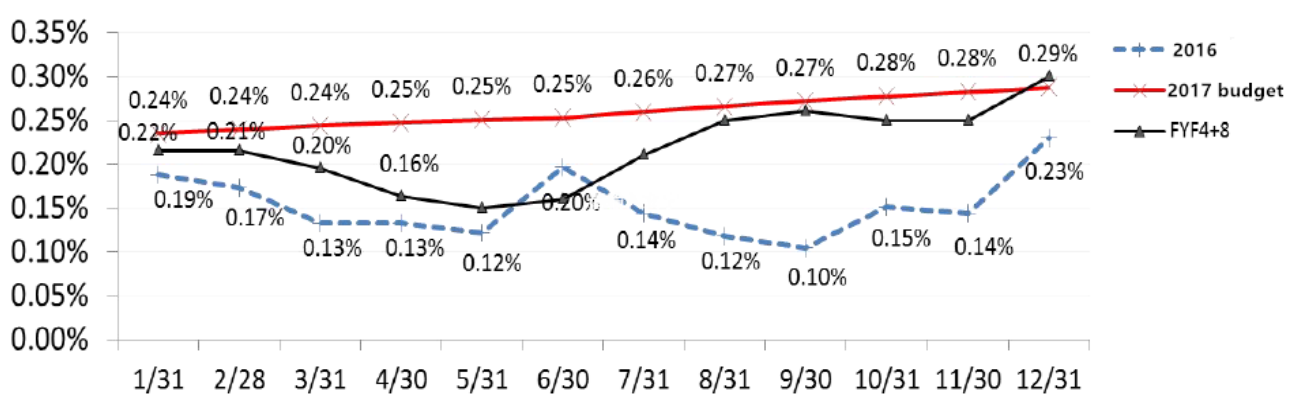

Figure 3. The non-performing loan ratios of the Small and Medium-sized Enterprises (SEMs) in the GNB in 2017 budget

Source: GNB, Retrieved June 18, 2018 http://www.gdnybank.com/index.html

From all these core indicators of credit risk supervision, GNB does meet the approved standard. However, in order to meet the supervision requirements of credit risk management set by the People's Bank of China, Chinese commercial banks have formed a set of methods to reduce the actual non-performing loans. In GNB, the average value of the reported monthly non-performing loan ratios is lower than the annul non-performing loan ratio in reality. Meanwhile, the reported annual non-performing loan ratios of both mortgage business and small and medium-sized enterprise loan business are smaller than the real ones. This means that the GNB's actual rate of non-performing loans is higher than the disclosure value. This indicates potential risks of the bank and credit risk management issues are becoming increasingly apparent (Liu, 2014).

\section{Problems in Credit Risk Management in the GNB}

According to the latest data on credit assets in GNB's annual reports, the bank has the following problems in credit risk management. Han (2016) argued that the credit scale of GNB has expanded rapidly but the level of credit risk management needs improvement. In 2006, the bank had just completed its reorganization of assets with total assets of only 8 billion 131 million yuan and deposits totalling 7 billion 397 million yuan. In 2011, the total assets reached 
83 billion 241 million yuan and the total deposits amounted to 30 billion 392 million yuan, which showed that the assets increased by ten times and deposits increased by four times. By the end of 2016, the total assets of the bank reached 203 billion 860 million yuan. In just five years, the total assets of the bank again increased by 2.5 times. With such a rapid expansion rate, some serious credit risk management problems were gradually emerging, such as non-performing loans increasing year by year and default risk of loans associated with each other. In 2009, the total amount of loans to GNB's seven largest customers was 1 billion 71 million yuan while the total investment of the seven shareholders was only 1 billion 34 million yuan. This means using the loan as equity capital. In 2011, the loan concentration of a single group customer was more than the regulatory standard $(\leq 10 \%)$, reaching $10.1 \%$. After five years of adjustment, the data remained above the regulatory standard, reaching 10.30\% in 2016 (GNB Annual Report, 2011-2016).

The internal control system of GNB is not perfect. The supervision and evaluation of credit management is not properly in place. This leads to a lot of indiscriminate investment, indiscriminate loans, and disorderly guarantees. For example, the loan approvers did not pay enough attention to one loan only because the customer was an old customer or was an acquaintance of a superior. Some loan business managers even helped customers to apply to extend the duration of loan contracts and change the important terms without the prior written consent of the guarantor, which resulted in partial or total invalidity of the contract (Wang and Xie, 2013).

For trade credit and cross-regional credit, the loan approval of GNB has not been prudent enough. For example, for a customer who did not meet the entry criteria, the bank relaxed the access threshold and adopted the customer in the form of trade financing. After the loan was issued, it was confirmed that the customer was nominally a stainless-steel company but was actually a financing platform. By engaging in large transactions frequently associated with subordinate trading companies, the customer invented a flow of business transactions to obtain bank credit funds. Meanwhile, effective means in dealing with unexpected defaults is lacking. For instance, the bank is difficult to obtain the support of the local police and government when a loan is overdue and the bank needs to take back the buildings of the firm. The regional protectionism from local government also makes it relatively difficult for the bank to deal with loan business with cross-regional collaterals (Han, 2016).

\section{Counter-Measures for Strengthening the Credit Risk Management in the GNB}

The future development goal of GNB is to become a new national bank of influence and to be a distinctive regional bank with a competitive advantage. By understanding the whole strategy, the following measures could help to solve the problems above and strengthen the management of the Bank who is now under the booming period.

The first method is the introduction of advanced credit risk management techniques. Basel III uses a large number of models to measure the credit risk and the quantitative method is more scientific to adapt to the development tendency of managing credit risks compared to the qualitative method. Therefore, GNB should combine the international quantitative credit risk management models with the special situation of the bank. For example, in the customer relationship management system, the key point is to track the risk and profit of each customer. Citibank used specialised software in this area and achieved good results, which is worth noting (Huang, 2013).

At the same time, the credit approval process of GNB went through the following three steps: the pre-loan investigation, examination and approval and the post-loan evaluation. Only when these steps are linked together effectively and organically can any breach of procedure and administrative interference be effectively eliminated (Han, 2016). Professionals in risk management, finance and law should form an investigation team to provide an independent report before loan. The members of the examination and approval should have higher qualifications than the investigation team, and should have more than five years of relevant professional experience and Bachelor's degree or above. Post evaluation should focus on the change of quality of borrowers' credit assets and preparation of an early repayment of loans (Han, 2013).

The second strategy is to increase the training of credit staff. Risk management personnel in different positions should have different trainings. The staff, who have more than two years' experience in credit work and have further training potential, should be trained to gradually become the business and technical backbone. The training of newly recruited college students and new entrants from other banks will enable them to become familiar with the bank's regulations and business processes. In addition, a professional skill training mechanism should be established for each month. The head of credit risk management department and external experts would conduct business training and communicate with loan approvers and loan business managers each month (Han, 2016).

With regards to the cross regional credit business, the Bank has been advised to prudently carry out the loan business with cross-regional small and medium-sized enterprises. For regions with higher risk levels and over-capacity 
industries, there will be no increase in off-site cargo mortgage credit. Although the loans are guaranteed by trade, the borrower's credit status and the first source of repayment should still be the first concern of the bank. The bank cannot reduce the borrower's access standards only because the loan is secured by trade (Liu, 2014).

Finally, GNB's existing pledge business is mostly carried out around commodities such as raw materials. Meanwhile, the Chinese over-capacity issues are outstanding currently, commodity prices are falling sharply and the accounts receivable turnover rates of some enterprises are falling sharply. This has resulted in a huge increase in the probability of corporate capital failures and defaults. In order to cope with the dilemma, the Head Office and the branches of the bank should strengthen ties with each other and build a more comprehensive credit information sharing system (Han, 2016).

\section{Suggestions for Strengthening Credit Risk Management of Chinese Commercial Banks Similar to the GNB}

The target for contemporary emerging commercial banks in China should refer to GNB's experience when conducting their small and medium-sized enterprise (SME) loan business, which is 'making the bank become the best services provider to SMEs and making SMEs become the major contributor of profits to the bank' (GNB Financial Report, 2016).

Banks should collect related data in target customer industries and establish a customer database shared by the whole banking industry to reduce the default risk of small and micro-enterprise credit business. At the same time, GNB selects the cultural industry, energy industry, and the environmental protection industry as the long-term target for loan business. The bank also cooperates with an Internet financial services platform. This helps the bank to make full use of the third party funds to reduce costs and transfer risks. The design of a range of online loan products, such as the vegetables industry loans and shipping industry loans, has been showed to be very popular in Zhanjiang city in Guangdong Province (Liu, 2014).

The idea of building a credit factory also can be promoted among commercial banks in Guangdong province. The credit factory idea means the pipe-lined division of labour within the credit risk management department of a bank which imitates the assembly line concept of manufacturing plants. This helps to separate the loan business department from the loan approval department clearly and improves efficiency. In order to build the credit factory, GNB took on board the more mature credit factory operations from the Pingan Bank (another commercial bank in Guangdong province) and have already achieved encouraging improvements (Shen, 2015).

\section{Postscript}

This case study focuses on the credit risk management of the GNB from 2011 to 2016. It shows the successful strategies of the GNB that mitigates credit risk. Therefore, the suggestions on credit risk management for this bank provide inspirations for other Chinese commercial banks. It analysed the current situation and problems of the GNB in controlling credit risk by using economic data in several sectors from 2011 to 2016. The empirical details in Figures and Tables demonstrate how GNB strenuously managed the relationship between profits and defaults in the last five years of its operations.

The GNB is able to take the lead in Guangdong province because it firstly seized the personal consumption loan market and the small and medium-sized enterprise loan business where the defaults are relatively low and profits are relatively high. At the same time, the deeper reason is that this bank is adept at choosing exactly where to develop for loan business at the long run such as the environmental protection industry. Therefore, GNB can enlighten other Chinese commercial banks in credit risk management. It can also be adopted by other commercial banks around the globe.

There are limitations in this case study. Although this cases study has put forward the concept of combining the Credit Risk Plus Model with China's actual condition, it has not provided a specific model. Moreover, Basel III requires banks to link credit risk with market risk and operational risk aiming to introduce a comprehensive risk management model. However, this work still lacks an overall grasp and relevant consideration of various risks. Finally, financial risks include banking risk, insurance risk and securities risk. This work has only analysed one part of the total financial risk management - commercial banks' credit risk. Only if this risk builds an organic unity with other kinds of financial risks, it is possible to achieve the goal of the Chinese commercial banks - Security, Liquidity and Profitability. Despite these limitations, the GNB case study provides valuable insights for bank managers and policy makers. The Chinese commercial banking can take GNB's strategic experiences into consideration and make plans for better credit risk management. 


\section{References}

Cai, J. L. (2015). The research and analysis of the credit management system of Huizhou branch in Guangdong Nanyue Bank. Ph.D. thesis, Yunnan University.

GNB. (2011). Guangdong Nanyue Bank 2011 Financial Report. Zhanjiang: Guangdong Nanyue Bank.

GNB. (2012). Guangdong Nanyue Bank 2012 Financial Report. Zhanjiang: Guangdong Nanyue Bank.

GNB. (2013). Guangdong Nanyue Bank 2013 Financial Report. Zhanjiang: Guangdong Nanyue Bank.

GNB. (2014). Guangdong Nanyue Bank 2014 Financial Report. Zhanjiang: Guangdong Nanyue Bank.

GNB. (2015). Guangdong Nanyue Bank 2015 Financial Report. Zhanjiang: Guangdong Nanyue Bank.

GNB. (2016). Guangdong Nanyue Bank 2016 Financial Report. Zhanjiang: Guangdong Nanyue Bank.

GNB. (2017). General situation of the Guangdong Nanyue Bank. Retrieved July 18, 2017, from http://www.gdnybank.com/abstract/index.html

Han, C. J. (2013). The development of city commercial banks like Guangdong Nanyue Bank. Contemporary Economy, (24), 9-11.

Han, C. J. (2013). The eight key words for deciding the future of small and medium banks like Guangdong Nanyue Bank. Bankers, (11), 38-40.

Han, C. J. (2016). Financial innovation is the source of the vitality of supply side reform. China's Banking Industry, (3), 1-2.

Huang, H. (2013). Construction of the core value of Guangdong Nanyue Bank. Chinese Management Information, (20), 38-39.

Kong, L. (2014). The design and implementation of human resource management system in Guangdong Nanyue Bank. Ph.D. thesis, Chongqing University.

Liu, B. (2014). Research on the core competitiveness of Guangdong Nanyue Bank. Ph.D. thesis, South China University of Technology.

Shen, R. H. (2015). Credit plants for small and micro enterprise credit: financial model and technological platform innovation to lead the service to entity economy. Financial Computerization, (7), 42-43.

Wang, L., \& Xie, X. (2015). Study on the efficiency of medium and long term incentive mechanism of urban commercial banks. Chinese and Foreign Enterprisers, (1), 38-41.

Wang, X. Y. (2013). Guangdong Nanyue Bank: a rising star: an interview with the chief information officer of Guangdong Nanyue Bank - Mai Zhiwen. Financial Times of Science and Technology, (6), 22-22.

Yang, Z. Y. (2015). The research on small and medium enterprise credit risk management of Guangdong Nanyue Bank. Ph.D. thesis, Hunan University.

Yang, Z. Y. (2016). Research on the expanding strategy of retail business in the Changsha branch of Guangdong Nanyue Bank. Ph.D. thesis, Hunan University.

Ye, C. Q. (2017). The new generation core system of products in Guangdong Nanyue Bank: documentary interview with Guangdong Nanyue Bank's director of science and technology - Mai Zhiwen. Financial Times of Science and Technology, (2), 10-15. 